\title{
Bioactivity of the organic extracts of Annona vepretorum on Tetranychus urticae (Acari: Tetranychidae)
}

\author{
Maria Herlândia de Araújo Fernandes(1), Karen Oliveira de Menezes ${ }^{(2)}$, \\ Adriana Maria de Souza(2), Jackson Roberto Guedes da Silva Almeida ${ }^{(3)}$, \\ José Eudes de Morais Oliveira( ${ }^{(4)}$ and Rita de Cássia Rodrigues Gonçalves Gervásio(1)
}

\begin{abstract}
(1)Universidade Federal do Vale do São Francisco (Univasf), BR-407, Km 119, Lote 543, Projeto de Irrigação Senador Nilo Coelho, s/no, CEP 56300-990 Petrolina, PE, Brazil. E-mail: herlandia_fernandes@hotmail.com, rita.gervasio@univasf.edu.br (2)Universidade Federal do Piauí, Campus Prof. ${ }^{a}$ Cinobelina Elvas, BR-135, Km 3, Planalto Horizonte, CEP 64900-000 Bom Jesus, PI, Brazil. E-mail: kren.oliveira@hotmail.com, adrianasouzabio@hotmail.com (3)Univasf, Avenida José de Sá Maniçoba, s/no, Centro, CEP 56304-205, Petrolina, PE, Brazil. E-mail: jackson.guedes@univasf.edu.br (4)Embrapa Semiárido, BR-428, Km 152, s/noo, Zona Rural, CEP 56302-970 Petrolina, PE, Brazil. E-mail: eudes.oliveira@embrapa.br
\end{abstract}

\begin{abstract}
The objective of this work was to evaluate the lethal and sublethal toxicity of hexane and methanolic extracts from the leaves of Annona vepretorum (Annonaceae) on Tetranychus urticae (Acari: Tetranychidae). The methanolic extract toxicity was evaluated by Potter tower application (topical + residual effect) and by immersion of Canavalia ensiformis leaf disks in the extract solution (residual contact effect). The hexane extract toxicity was evaluated exclusively through residual contact effect. Sublethal effects of the methanolic extract were evaluated through $\mathrm{LC}_{50}$ on the females. Mite preference for feeding and oviposition was evaluated by multiple choice tests, between the control and the extract concentrations, using the hexane and methanolic extracts. Estimated $\mathrm{LC}_{50}$ for the methanolic extract was $10.96 \mathrm{mg} \mathrm{mL}^{-1}$ for the topic + residual effect and $22.07 \mathrm{mg} \mathrm{mL}^{-1}$ for the residual effect. Estimated $\mathrm{LC}_{50}$ for the hexane extract was $50.61 \mathrm{mg} \mathrm{mL}^{-1}$. The methanolic extract at the previously estimated $\mathrm{CL}_{50}$ interfered in the fecundity and longevity of females, differing significantly from the control treatment. In the multiple choice tests, for both extracts, mites showed a significant preference for the control, both for feeding and oviposition. Annona vepretorum has acaricide effect and constitutes a botanical source with great potential for controlling T. urticae.
\end{abstract}

Index terms: acetogenins, botanical acaricide, botanical extracts, integrated pest management, pesticide resistance, two-spotted spider mite.

\section{Bioatividade de extratos orgânicos de Annona vepretorum sobre Tetranychus urticae (Acari: Tetranychidae)}

Resumo - O objetivo deste trabalho foi avaliar a toxicidade letal e subletal dos extratos hexânico e metanólico das folhas de Annona vepretorum (Annonaceae) sobre Tetranychus urticae (Acari: Tetranychidae). A toxicidade do extrato metanólico foi avaliada por meio da aplicação em torre de Potter (efeito tópico + residual) e por imersão de discos de folhas de Canavalia ensiformis na solução do extrato (efeito de contato residual). A toxicidade do extrato hexânico foi avaliada unicamente por meio do efeito de contato residual. Os efeitos subletais do extrato metanólico foram avaliados por meio da $\mathrm{CL}_{50}$ sobre as fềmeas. A preferência do ácaro por alimentação e oviposição foi avaliada por testes de múltipla escolha, entre o tratamento controle e as concentrações dos extratos, com os extratos hexânico e metanólico. A CL $\mathrm{L}_{50}$ estimada do extrato metanólico foi de $10,96 \mathrm{mg} \mathrm{mL}^{-1}$ para o efeito tópico + residual e de $22,07 \mathrm{mg} \mathrm{mL}^{-1}$ para o efeito residual. $\mathrm{A} \mathrm{CL}_{50}$ estimada para o extrato hexânico foi de $50,61 \mathrm{mg} \mathrm{mL}^{-1}$. O extrato metanólico na $\mathrm{CL}_{50}$ previamente estimada interferiu na fecundidade e na longevidade das fêmeas e diferiu significativamente do tratamento controle. Nos testes com múltipla escolha, para ambos os extratos, os ácaros apresentaram preferência significativa pelo controle, quanto à alimentação e à oviposição. Annona vepretorum apresenta efeito acaricida e constitui uma fonte botânica de grande potencial no controle de T. urticae.

Termos para indexação: acetogeninas, acaricidas botânicos, extratos botânicos, manejo integrado de pragas, resistência a pesticidas, ácaro-rajado.

\section{Introduction}

Tetranychus urticae Koch (Acari: Tetranychidae) is one of the most polyphagous species among the phytophagous mites, and it is a key pest that attacks many crops (Roh et al., 2011), among which are several fruit, vegetable, and plant species (Van Leeuwen et al., 2007; Moraes \& Flechtmann, 2008). 
The control of $T$. urticae occurs chiefly by applying synthetic acaricides (Van Leeuwen et al., 2010); however, the excessive use of acaricides has been under serious consideration over the recent years, particularly as to their effect on environmental contamination, mammalian toxicity, mortality of natural enemies (Silva et al., 2006), and selection of resistant populations (Nicastro et al., 2010). The mite T. urticae is prominent as one of the arthropods showing the highest resistance to both acaricides and synthetic insecticides (Whalon et al., 2008), with population resistance reported for 94 different active ingredients (APRD, 2016).

Botanical acaricides have been intensely researched and are considered a promising alternative as potential substitutes for synthetic acaricides in agricultural pest control. Their advantages are mostly related to the fact that they are biodegradable compounds, slightly harmful to environment, nontoxic to nontarget species, and also to their capacity to avoid or retard the beginning of resistance (Krinski et al., 2014), as these products are composed of a complex mixture of constituents.

Over the recent years, crude extracts drawn from the Annonaceae seed, leaves, barks, twigs, and fruit have been widely tested to ascertain their bioactivity on arthropods of agricultural or medical importance (Isman \& Seffrin, 2014). The insecticide/ acaricide potential of the Annonaceae is related to the acetogenins, a class of natural products exclusively found in this family (Ocampo \& Ocampo, 2006).

The Annonaceae stands out from the several botanical families that release metabolites that are toxic to the phytophagous mites, and their derivatives have been widely tested as an alternative to control mites (Madhumitha et al., 2012; Ribeiro et al., 2014; Alves et al., 2015). Brazil accounts for 29 genera of this family, which comprises nearly 392 species (Maas et al., 2015), several of which, particularly those of the genus Annona, have been investigated for pest control (Krinski et al., 2014; Ribeiro et al., 2016). However, in the literature, no reports were found on the acaricide potential of Annona vepretorum Mart., popularly known as "araticum" or "pinha da caatinga", a species endemic to Brazil that is widely distributed across the semiarid regions.

Annona vepretorum contains an abundance of phenolic compounds, steroids, terpenoids, and flavonoids (Diniz et al., 2013), as well as monoterpenes and sesquiterpenes (Araújo et al., 2015); these compounds show antinociceptive, anti-inflammatory properties (Almeida et al., 2014), besides being able to affect the central nervous system of the mites (Diniz et al., 2013).

The objective of this work was to evaluate the lethal and sublethal toxicity of hexane and methanolic extracts from the leaves of $A$. vepretorum (Annonaceae) on T. urticae (Acari: Tetranychidae).

\section{Materials and Methods}

Leaves of A. vepretorum were gathered in June 2015, from a Caatinga area, in the Agricultural Sciences Campus of the Universidade Federal do Vale do São Francisco (09 $19^{\prime} 38^{\prime \prime} \mathrm{S}, 40^{\circ} 33^{\prime} 01^{\prime \prime} \mathrm{W}$, at $385 \mathrm{~m}$ altitude). The species exsicata, assigned to the lot no. 18350, is deposited in the Herbário Vale do São Francisco at the aforementioned university.

To prepare the extracts, the leaves were packed in a kraft paper bag and placed in a circulating-air oven, at $40^{\circ} \mathrm{C}$ on average, for 72 hours. After drying, the material was ground in a knife mill until it was finely powdered. The extract was prepared at room temperature by macerating the powder with hexane (ratio $1: 4 \mathrm{~m} / \mathrm{v}$ ), in a stainless steel percolator, for 72 hours. The extract was then filtered through cotton wool. More hexane was added to the residue, and the whole procedure was replicate for six times, to garantee a high extraction yield. Evaporation of the liquid phase from the solvent was then performed at $50^{\circ} \mathrm{C}$ using a rotary evaporator (rotavapor) at $-600 \mathrm{mHg}$. The filtered solution was then poured into a pre-weighed, labeled glass vial, and left open to enable the maximum solvent evaporation. Once the hexane extract was obtained, the methanol extraction was performed on the residual cake, following the previously described methodology. The extracts were kept in domestic refrigerator $\left(\sim 5^{\circ} \mathrm{C}\right)$. The extract yield was calculated by the following expression: Yield $(\%)=[$ (mass of the extract $/$ mass of the dried plant material $) \times 100]$.

The mites of the experiment were obtained from a laboratory rearing, maintained under controlled conditions $\left(25 \pm 1^{\circ} \mathrm{C}, 70 \pm 10 \%\right.$ relative humidity, and 12-hour photophase) on bean plants Canavalia ensiformis L. (Leguminosae).

The methanolic extrac toxicity was assessed in pre-tests using diluted concentrations in factor $10(0.1$,

Pesq. agropec. bras., Brasília, v.52, n.9, p.707-714, set. 2017

DOI: 10.1590/S0100-204X2017000900002 
1.0, 10.0, and $\left.100.0 \mathrm{mg} \mathrm{mL}^{-1}\right)$. The preliminary tests enabled the establishment of seven concentrations, which promoted mite mortality from 0 to $100 \%$, as follows: $0.9,1.9,3.7,7.5,15,30$, and $60.0 \mathrm{mg} \mathrm{mL}^{-1}$. The methanolic extract was dissolved in distilled water and acetone (10\%). Distilled water and acetone (10\%) were used as controls. The acaricide Diafenthiuron (Polo $500 \mathrm{SC}$, Syngenta S.A.), at $2 \mathrm{mg} \mathrm{mL}^{-1}$ concentration, was used as the positive control.

Methanolic extract toxicity on mites was determined by the residual + topical effect, or by the residual effect only. At first, rearing "arenas" were mounted on of 9-cm diameter Petri dishes, with water-moistened polyethylene sponge, and filter paper discs of identical dimensions were placed on them. For the tests involving the topical + residual effect, $3 \mathrm{~cm}$ diameter leaf discs of C. ensiformis were placed on the "arenas", with the edges covered with paper towel pieces to prevent mites from escaping. Then, 10 adult females of T. urticae were transferred onto the leaf discs by using a fine brush. Next, $2 \mathrm{~mL}$ of each extract concentration was applied per leaf disc, as well as $2 \mathrm{~mL}$ of the control, using Potter's tower, at $5 \mathrm{psi} \mathrm{pol}^{-2}$ pressure.

The toxicity by residual effect only was determined according to the method no. 4 of IRAC (Insecticide Resistance Action Committee) (IRAC, 2009). The applications were done by immersing $C$. ensiformis discs with $3 \mathrm{~cm}$ diameter, for $5 \mathrm{~s}$, in a beaker, employing different concentrations of the extract and the control. These discs were then conditioned on the "arenas" in the Petri dishes. After solvent was dried for about 1 hour, the disc edges were covered with paper towel bits to prevent mites from escaping, and the 10 adult females were transferred onto each treated disc.

A completely randomized design was adopted for the experiments, and the Petri dishes were placed in an acclimatized chamber (BOD). Dishes were watered daily to maintain the turgency of the leaf discs. For both experiments, 15 replicates were done per concentration, using 150 mites per treatment. The assays were repeated in different days, performing five replicates of each treatment per day.

Mortality was estimated using a Stereo Microscope after 24, 48, and 72 hours of extract application, and mites that did not move to a distance equivalent to their body lengths, when touched with a fine brush, were considered dead.

The hexane extract toxicity was determined by the bioassays done according to the IRAC method no. 4 , from the series of susceptibility tests (IRAC, 2009). First, preliminary tests were conducted, from which five concentrations $\left(6.2,12.5,25.0,50.0\right.$, and $\left.100.0 \mathrm{mg} \mathrm{mL}^{-1}\right)$ were established. These doses were solubilized only in acetone, as it showed good solubilization capacity in light of the physico-chemical characteristics of the hexane extract. The extract concentrations were applied, as previously described, according to the test for residual effect toxicity. The procedures were similar to those of the previous experiment as to the preparation of the experimental units, experimental design, number of replicates, experimental conditions, evaluation, and statistical analysis of the data.

The methanolic extract effect on mite reproductive parameters was assessed by $\mathrm{LC}_{50}$, previously estimated in the toxicity test of the methanolic extract with topical + residual effect. For the bioassay, it was essential that females of the same age were used. To accomplish this, in each Petri dish "arena", three $C$. ensiformis leaf discs ( $2 \mathrm{~cm}$ diameter each) were placed with one female on each of them, with a 24-hour oviposition period. Next, the females and excess eggs were removed, leaving only three eggs per disc. After the larvae hatched out, only one individual per disc was selected to be followed until maturity. Later, these approximately 2-day-old adult females were given $2 \mathrm{~mL}$ applications of the extract $\mathrm{LC}_{50}$ dose per dish, via Potter tower, as well as of the control treatment [distilled water and acetone (10\%)]. After the application, a male from the maintenance rearing was released onto each disc, and caution was exerted to replace it in case of mortality. For each treatment, 41 females were used, and each one was considered as a replicate. Fecundity, egg viability, and longevity of the females were evaluated daily.

To follow the egg viability, "arenas" with leaf discs were identified based on the number of eggs laid per female. The eggs were counted, and then carefully transferred to their respective "arenas", with the aid of a fine brush. Daily evaluations of these arenas were made, and the active immature forms that were observed were counted and discarded. The mortality dates of females were carefully recorded to determine their longevity.

For the multiple choice test, the bioassays were conducted using both the organic extracts at the same concentrations $\left(1.9,3.7,7.5,15.0\right.$, and $\left.30.0 \mathrm{mg} \mathrm{mL}^{-1}\right)$. The hexane extract was solubilized only in acetone, while the methanolic extract was dissolved in distilled water and acetone (10\%). The leaf discs of C. ensiformis, with $5 \mathrm{~cm}$ diameter, were divided into equal areas, 
maintaining $0.3 \mathrm{~cm}$ neutral space between them. One of the areas was immersed in the control solution for $5 \mathrm{~s}$, while the another area was soaked in the extract solution. Then, the discs were arranged individually on the "arenas". The treated discs were left in free air for about one hour, until the solvent completely evaporated. The disc edges were covered with paper towel bits to prevent mites from escaping. Then, 10 adult mite females were released onto each disc center, in the neutral area. For each treatment, 15 replicates were performed. After 24 hours, the number of mites and eggs in the treated and untreated disc areas was counted. Before the bioassay, a blank test was done, to ascertain whether the "arenas" influenced the choice of mites for the treatment. The same procedures used in the bioassay were followed in the blank test; however, leaf discs in the blank test were left untreated.

The lethal concentrations (CLs) of the hexane and methanolic extracts were determined using the Probit analysis (Finney, 1971), using the Polo-Plus 2.0 program (LeOra Software, 2005). The $\mathrm{LC}_{50}$ and $\mathrm{CL}_{99}$ values were established with the mortality recorded after 72 hours of evaluation.

The data of the reproductive parameters, obtained after the bioassay using the methanolic extract, were analyzed by the Student's t test, at $5 \%$ of probability, and the means observed in the two treatments were compared. For the multiple choice test, the findings were subjected to the frequency of choice analysis, and evaluated using the chi-square test. The statistical program SAS (SAS Institute Inc., Cary, NC, USA) was used in all the analyses.

\section{Results and Discussion}

After the plant material was dried and milled, $448.0 \mathrm{~g}$ of the dry powder was derived from 1,148 $\mathrm{g}$ fresh leaves. The hexane extract of $A$. vepretorum leaves gave $3.9 \%$ yield, whereas the methanolic extract gave $9.7 \%$ yield in relation to the dry powder weight.

The methanolic extract of $A$. vepretorum leaves was considered as most toxic for T. urticae. Its direct application onto females showed higher toxicity $\left(\mathrm{LC}_{50}\right.$ at $10.96 \mathrm{mg} \mathrm{mL}^{-1}$ ) for the topical + residual effect than for the residual effect alone $\left(\mathrm{LC}_{50}\right.$ was $\left.22.07 \mathrm{mg} \mathrm{mL}^{-1}\right)$. The estimated $\mathrm{LC}_{50}$ for the hexane extract was 50.61 $\mathrm{mg} \mathrm{mL} \mathrm{m}^{-1}$. Therefore, the methanolic extract was more toxic than the hexane extract, which was also observed while assessing the $\mathrm{CL}_{99}$ (Table 1).

The bioactivity noted in the extracts indicates the possible presence of secondary metabolites, such as steroids, terpenoids, and phenolic compounds, and even of the acetogenins, common to the Annonaceae plant family. However, it is still essential to identify the chemical constituents responsible for the acaricidal effect. In arthropods, the acetogenins are known to block the respiratory chain in the NADH-ubiquinone reductase cycle (complex I), and to decrease the cellular ATP levels (Alali et al., 1999).

Extracts of annonaceous plants from different species have exhibited satisfactory bioactivity against various mite species. Maciel et al. (2015) reported that the ethanolic extract of Annona muricata showed a good potential for the control of T. urticae, inducing mite mortality, egg toxicity, as well as repellency and residual effects. Lima et al. (2014) showed that $5.0 \%$ concentration of the organic seed extract of $A$. muricata was efficient against $T$. evansi. Ribeiro et al. (2014) compared the efficacy of A. mucosa seed extract with natural and synthetic acaricides commercially available for Panonychus citri control, and discovered that, irrespective of the exposure time, the lethal effect of the extract showed no significant difference from that exerted by the biopesticide Azamax, and that, together with this product, the extract treatment offered the highest percentage of mortality.

In the present study, both the employed solvents showed distinct polarities for the extraction of $A$. vepretorum compounds.Therefore, it was assumed that the acetogenins varied from being very polar - when extracted by water, ethyl alcohol, and methanol - , to being nonpolar when extracted by hexane (Bobadilla et al., 2005). However, there are evidences that extracts obtained with solvents having low and medium polarity are more efficient. In their work, Kamaraj et al. (2004) evaluated bark extracts of A. squamosa from different solvents (hexane, chloroform, ethyl acetate, acetone, and methanol), and observed a moderate larvicidal activity on Anopheles subpictus Grassi and Culex tritaeniorhynchus Giles (Diptera: Culicidae), regardless of the solvent used. The methanolic extract was observed to have the highest toxic effect, with $\mathrm{LC}_{50}$ of $93.80 \mathrm{mg} \mathrm{L}^{-1}$ for A. subpictus, and $104.94 \mathrm{mg} \mathrm{L}^{-1}$ for C. tritaeniorhynchus. Another study reported $\mathrm{LC}_{50}$ of $23.06 \mu \mathrm{g} \mathrm{mL}^{-1}$ for the

Pesq. agropec. bras., Brasília, v.52, n.9, p.707-714, set. 2017

DOI: 10.1590/S0100-204X2017000900002 
ethanolic extract of $A$. crassiflora stem bark against Aedes aegypti, while $\mathrm{LC}_{50}$ of the hexane extract was $264.15 \mu \mathrm{g} \mathrm{mL}^{-1}$ (Rodrigues et al., 2006).

The bioactivity of the plant extracts may vary according to the species and vegetative structure of the plants used for the extraction. It is quite normal for different plant parts to show qualitative and quantitative differences as to their chemical constituents (Shaalan et al., 2005). Acetogenins occur in the leaves, branches, roots and, particularly, in the Annonaceae seed (Bermejo et al., 2005; Ribeiro et al., 2013). Thus, it is assumed that the application of other plant structures of $A$. vepretorum, like seed, can yield even better results with lower lethal doses. This hypothesis is based on the findings reported by Maciel et al. (2015), after their investigation with $A$. muricata seed extracts, and their result for $\mathrm{LC}_{50}$ of $3.29 \mathrm{mg} \mathrm{L}^{-1}$ on T. urticae.

The toxicity tests evaluating topical + residual effect and the residual effect alone yielded $100 \%$ mortality of $T$. urticae females, in just 48 hours after applying the synthetic acaricide Diafenthiuron $\left(2 \mathrm{mg} \mathrm{L}^{-1}\right)$. Mortality increased with the time of evaluation and the concentration used of the methanolic and hexane extracts.

The methanolic extract showed a speedier toxicity on $T$. urticae, when evaluating the topical + residual effect, with $93 \%$ mortality in the first 24 hours. In the evaluation of the residual effect alone, $65 \%$ mortality was recorded. The combined effect of the direct application on the mite (topical effect), together with the residual effect on the leaf discs used as feed by the mites, resulted in the quickest mortality of the topical + residual effect. Besides, the toxicity of the extract in this instance occurred through the ingestion of leaves and by contact with the body.

Mercado et al. (2014) determined the direct-contact toxicity and residual effect of the methanolic extract of six plant species of the families Asteraceae, Solanaceae, Verbenaceae, and Apiaceae on T. urticae, and reported a highly increased mortality level in the treatments that involved a topical + residual effect. The treatment with the Baccharis tola extract (Asteraceae), at $2.5 \%$ concentration, resulted in $94 \%$ mortality by topical effect, while for the residual contact effect, even at $10 \%$ concentration, it caused $23 \%$ mortality.

Plant secondary metabolites, besides causing mortality, can also reduce the mite fertility and inhibit oviposition and feeding, apart from deterrence and repellency (Isman, 2006; Carneiro et al., 2011). In the present work, we observed that the methanolic extract exerted a significant effect on the parameters of fecundity and longevity, but had no effect on egg viability (Table 2). Oviposition inhibition and the reduction of egg quantity are crucial effects of the plant extracts on arthropod reproduction (Costa et al., 2004). It has been recognized that when an individual mite is unable to feed on the treated leaf, the number of eggs will consequently decrease in response to the stress caused by the extract (Pontes et al., 2011). Among other factors, the differences in female longevity may also be related to mite nutrition. In the multiple choice tests, the tested concentrations markedly decreased the frequency at which the females chose the leaf discs treated with the extracts, in comparison to the control (Figure 1). This expressive preference shown by the mites for the control treatment indicates the possible presence of compounds with repellent or locomotion-stimulating properties in these organic

Table 1. Toxicity determined by the lethal concentrations $\left(\mathrm{LC}_{50}\right.$ and $\left.\mathrm{LC}_{99}\right)$ of the topical + residual effects, or by the residual effect alone, of the methanolic and hexane leaf extracts of Annona vepretorum on the adult females of Tetranychus urticae 72 hours after exposure.

\begin{tabular}{lccccc}
\hline Effect & $\begin{array}{c}\text { Number } \\
\text { of mites }\end{array}$ & $\begin{array}{c}\text { Inclination } \pm \\
\text { standard error }\end{array}$ & $\begin{array}{c}\mathrm{LC}_{50}\left(\mathrm{mg} \mathrm{L}^{-1}\right) \\
(95 \% \mathrm{CI})\end{array}$ & $\begin{array}{c}\mathrm{LC}_{99}\left(\mathrm{mg} \mathrm{L}^{-1}\right) \\
(95 \% \mathrm{CI})\end{array}$ & $\chi^{2}$ \\
\hline & & Methanolic extract & & 15.47 \\
Topic + residual & 1,030 & $3.03 \pm 0.29$ & $10.96(7.16-14.19)$ & $64.25(21.78-51.06)$ & 5.91 \\
Residual & 1,025 & $2.44 \pm 0.22$ & $22.07(18.07-26.39)$ & $197.42(56.33-112.10)$ & \\
\hline & 719 & Hexane extract & & \\
Residual & $4.18 \pm 0.52$ & $50.61(30.13-65.59)$ & $182.33(76.72-264.15)$ & 7.49 \\
\hline
\end{tabular}

$\chi^{2}$, calculated chi-square value; and CI, confidence interval. 
extracts. The blank test $\left(\chi^{2}=0.7226, p=0.3953\right)$ showed that the "arenas" used in the experiment did not affect the choice of the mites by the treatments.

The choice of the females for oviposition usually reflects the selection of the feeding area, and the recorded percentages were very similar for both choices. The lowest percentage for oviposition, in the control treatment, was $83 \%$, which reached up to $100 \%$. Therefore, the number of eggs in the control and treated areas is linked to feed preference by the mites.

Besides exhibiting acaricidal activity, $A$. vepretorum extracts also acted on the biological and behavioral aspects of $T$. urticae. Therefore, even if they are not essentially lethal to the mites, some chemical compounds present in their extracts may indirectly contribute towards pest control, as they interfere with the biological cycle and, consequently, reduce the mite population density.
The extracts of $A$. vepretorum show great potential for the development of new, useful products for the integrated management of T. urticae. However, as this is a first study reporting the pesticidal activity of this

Table 2. Mean \pm standard deviation of the sublethal effects of the Annona vepretorum leaf extracts on the adult Tetranychus urticae females, at the median lethal concentration $\left(10.96 \mathrm{mg} \mathrm{mL}^{-1}\right)$ previously estimated.

\begin{tabular}{lccc}
\hline Treatment & $\begin{array}{c}\text { No. of eggs } \\
\text { per female }\end{array}$ & $\begin{array}{c}\text { Feasibility of } \\
\text { eggs (\%) }\end{array}$ & $\begin{array}{c}\text { Longevity of } \\
\text { females (days) }\end{array}$ \\
\hline Control & $54.95 \pm 2.36$ & $87.80 \pm 0.99$ & $15.41 \pm 0.78$ \\
Methanolic extract & $22.85 \pm 3.07^{*}$ & $88.66 \pm 1.76$ & $6.92 \pm 0.70 *$ \\
\hline T value & 8.27 & 0.42 & 8.02 \\
p-value & 0.0001 & 0.6753 & 0.0001 \\
\hline
\end{tabular}

*Significant by the $\mathrm{t}$ test, at $5 \%$ probability.

A

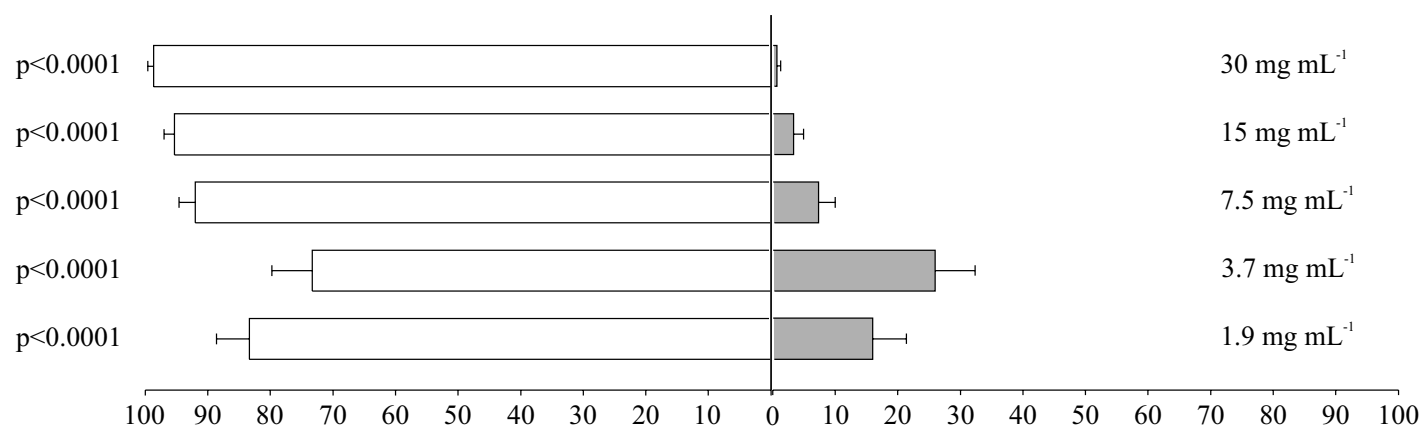

B

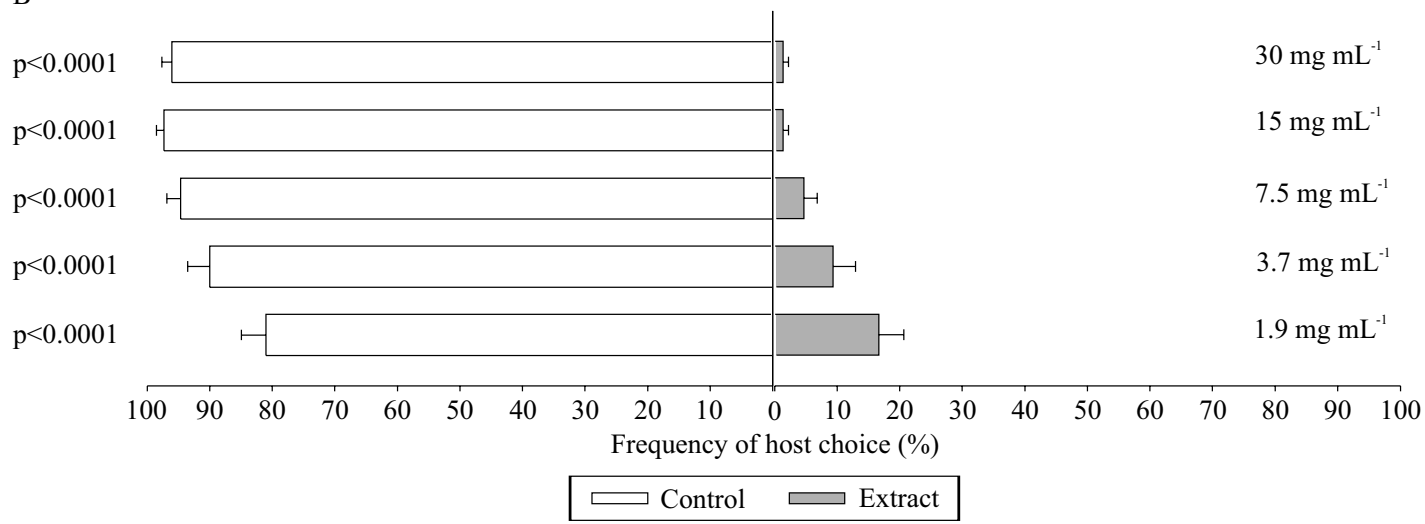

Figure 1. Mean frequency of Tetranychus urticae females on Canavalia ensiformis leaf discs treated or not with the methanolic (A) and hexane (B) extracts of Annona vepretorum. The treatments differed significantly from the control by the chi-square test, at $5 \%$ probability. 
plant species, more studies are required, particularly under field or semi-field conditions, in order to confirm the stability and efficiency of these extracts.

\section{Conclusions}

1. The methanolic and hexane leaf extracts of Annona vepretorum are toxic to Tetranychus urticae.

2. Organic extracts affect the reproductive parameters fecundity and longevity of $T$. urticae females.

3. The extracts are highly efficient in repelling the mites from the area under treatment, even at the lowest concentration of $1.9 \mathrm{mg} \mathrm{mL}^{-1}$.

\section{Acknowledgments}

To Coordenação de Aperfeiçoamento de Pessoal de Nível Superior (Capes), for the scholarship granted to the first author.

\section{References}

ALALI, F.Q.; LIU, X.-X.; MCLAUGHLIN, J.L. Annonaceous acetogenins: recent progress. Journal of Natural Products, v.62, p.504-540, 1999. DOI: 10.1021/np980406d.

ALMEIDA, J.R.G. da S.; ARAÚJO, C. de S.; PESSOA, C. do Ó.; COSTA, M.P. da; PACHECO, A.G.M. Atividade antioxidante, citotóxica e antimicrobiana de Annona vepretorum Mart. (Annonaceae). Revista Brasileira de Fruticultura, v.36, p.258-264, 2014. Edição especial. DOI: 10.1590/S010029452014000500030.

ALVES, D.S.; MOREJÓN, R.C.; MACHADO, A.R.T.; CARVALHO, G.A.; PINA, O.; OLIVEIRA, D.F. Acaricidal activity of Annonaceae fractions against Tetranychus tumidus and Tetranychus urticae (Acari: Tetranychidae) and the metabolite profile of Duguetia lanceolata (Annonaceae) using GC-MS. Semina: Ciências Agrárias, v.36, p.4119-4132, 2015. Suplemento 2. DOI: $10.5433 / 1679-0359.2015 v 36 n 6 S u p 12 p 4119$.

APRD. Arthropod Pesticide Resistance Database. 2016.

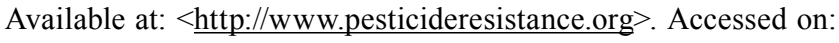
Mar. 222016.

ARAÚJO, C. de S.; OLIVEIRA, A.P. de; LIMA, R.N.; ALVES, P.B.; DINIZ, T.C.; ALMEIDA, J.R.G. da S. Chemical constituents and antioxidant activity of the essential oil from leaves of Annona vepretorum Mart. (Annonaceae). Pharmacognosy Magazine, v.11, p.615-618, 2015. DOI: 10.4103/0973-1296.160462.

BERMEJO, A.; FIGADÈRE, B.; ZAFRA-POLO, M.-C.; BARRACHINA, I.; ESTORNELL, E.; CORTES, D. Acetogenins from Annonaceae: recent progress in isolation, synthesis and mechanisms of action. Natural Product Reports, v.22, p.269303, 2005. DOI: 10.1039/B500186M.
BOBADILLA, M.; ZAVALA, F.; SISNIEGAS, M.; ZAVALETA, G.; MOSTACERO, J.L.; TARAMONA, L. Evaluación larvicida de suspensiones acuosas de Annona muricata Linnaeus «guanábana» sobre Aedes aegypti Linnaeus (Diptera, Culicidae). Revista Peruana de Biología, v.12, p.145-152, 2005. DOI: 10.15381/rpb. v12i1.2369.

CARNEIRO, A.P.; PEREIRA, M.J.B.; GALBIATI, C. Efeito biocida de Annona coriacea Mart 1841 sobre ovos e ninfas do vetor Rhodnius neglectus Lent 1954. Neotropical Biology and Conservation, v.6, p.131-136, 2011. DOI: 10.4013/nbc.2011.62.08.

COSTA, E.L.N.; SILVA, R.F.P.; FIUZA, L.M. Efeitos, aplicações e limitações de extratos de plantas inseticidas. Acta Biologica Leopoldensia, v.26, p.173-185, 2004.

DINIZ, T.C.; ARAÚJO, C. de S.; SILVA, J.C.; OLIVEIRA JÚNIOR, R.G. de; LIMA-SARAIVA, S.R.G. de; QUINTANS JÚNIOR, L.J.; NUNES, X.P.; ALMEIDA, J.R.G.S. da. Phytochemical screening and central nervous system effects of ethanolic extract of Annona vepretorum (Annonaceae) in mice. Journal of Medicinal Plants Research, v.7, p.2729-2735, 2013. DOI: 10.5897/JMPR2013.4482.

FINNEY, D.J. Probit analysis. Cambridge: University Press, 1971. 333p.

IRAC. Inseticide Resistance Action Committee. IRAC Susceptibility Test Methods Series: Method n. 4. 2009. Available at: <http://www.irac-online.org/content/uploads/Method_004_ v3_june09.pdf >. Accessed on: June 142016.

ISMAN, M.B. Botanical insecticides, deterrents, and repellents in modern agriculture and an increasingly regulated world. Annual Review of Entomology, v.51, p.45-66, 2006. DOI: 10.1146/ annurev.ento.51.110104.151146.

ISMAN, M.B.; SEFFRIN, R. Natural insecticides from the Annonaceae: a unique example for developing biopesticides. In: SINGH, D. (Ed.). Advances in Plant Biopesticides. New Delhi: Springer, 2014. p.21-33. DOI: 10.1007/978-81-322-2006-0_2.

KAMARAJ, C.; BAGAVAN, A.; ELANGO, G.; ZAHIR, A.A.; RAJAKUMAR, G.; MARIMUTHU, S.; SANTHOSHKUMAR, T.; RAHUMAN, A.A. Larvicidal activity of medicinal plant extracts against Anopheles subpictus \& Culex tritaeniorhynchus. Indian Journal of Medical Research, v.134, p.101-106, 2011.

KRINSKI, D.; MASSAROLI, A.; MACHADO, M. Potencial inseticida de plantas da família Annonaceae. Revista Brasileira de Fruticultura, v.36, p.225-242, 2014. Edição especial. DOI: 10.1590/S0100-29452014000500027.

LEORA SOFTWARE. POLO-Plus, POLO for Windows computer program, version 2.0. Petaluma, 2005.

LIMA, H.M.A.; RODRIGUES, V. de M.; VALENTE, E.C.N.; SANTOS, M.D. dos; DUARTE, A.G.; TRINDADE, R.C.P. Toxicidade do extrato orgânico de sementes de Annona muricata L. (Annonaceae) sobre Tetranychus evansi (Baker \& Pritchard, 
1960) (Acari: Tetranychidae) em tomateiro. Revista Brasileira de Biociências, v.12, p.201-205, 2014.

MAAS, P.; LOBÃO, A.; RAINER, H. Annonaceae. In: LISTA de espécies da flora do Brasil. Rio de Janeiro: Jardim Botânico, 2015. Available at: <http://floradobrasil.jbrj.gov.br/reflora/ floradobrasil/FB110219>. Accessed on: Apr. 32016.

MACIEL, A.G.S.; RODRIGUES, J.S.; TRINDADE, R.C.P.; SILVA, E.S.; SANT'ANA, A.E.G.; LEMOS, E.E.P. Effect of Annona muricata L. (1753) (Annonaceae) seeds extracts on Tetranychus urticae (Koch, 1836) (Acari: Tetranychidae). African Journal of Agricultural Research, v.10, p.4370-4375, 2015. DOI: 10.5897/AJAR2015.10201.

MADHUMITHA, G.; RAJAKUMAR, G.; ROOPAN, S.M.; RAHUMAN, A.A.; PRIYA, K.M.; SARAL, A.M.; KHAN, F.R.N.; KHANNA, V.G.; VELAYUTHAM, K.; JAYASEELAN, C.; KAMARAJ, C.; ELANGO, G. Acaricidal, insecticidal, and larvicidal efficacy of fruit peel aqueous extract of Annona squamosa and its compounds against blood-feeding parasites. Parasitology Research, v.111, p.2189-2199, 2012. DOI: 10.1007/ s00436-011-2671-2.

MERCADO, V.T.; CHUNG, S.J.; MESINA, R.V. Estudio preliminar del efecto acaricida de seis extractos metanólicos sobre la arañita bimaculada, Tetranychus urticae Koch. Idesia, v.32, p.37-45, 2014. DOI: 10.4067/S0718-34292014000200006.

MORAES, G.J. de; FLECHTMANN, C.H.W. Manual de acarologia: acarologia básica e ácaros de plantas cultivadas no Brasil. Ribeirão Preto: Holos, 2008. 308p.

NICASTRO, R.L.; SATO, M.E.; SILVA, M.Z. da. Milbemectin resistance in Tetranychus urticae (Acari: Tetranychidae): selection, stability and cross-resistance to abamectin. Experimental and Applied Acarology, v.50, p.231-241, 2010. DOI: 10.1007/s10493009-9304-9.

OCAMPO, D.M.; OCAMPO, R. Bioactividad de la familia annonaceae. Revista de la Universidad de Caldas, v.26, p.135$155,2006$.

PONTES, W.J.T.; OLIVEIRA, J.C.G. de; CÂMARA, C.A.G. da; ASSIS, C.P.O. de; OLIVEIRA, J.V. de; GONDIM JÚNIOR, M.G.C.; BARROS, R. Effects of the ethanol extracts of leaves and branches from four species of the genus Croton on Tetranychus urticae Koch (Acari: Tetranychidae). BioAssay, v.6, p.1-5, 2011. DOI: 10.14295/BA.v6.0.89.

RIBEIRO, L. do P.; VENDRAMIM, J.D.; BICALHO, K.U.; ANDRADE, M. dos S.; FERNANDES, J.B.; MORAL, R. de A.; DEMÉTRIO, C.G.B. Annona mucosa Jacq. (Annonaceae): a promising source of bioactive compounds against Sitophilus zeamais Mots. (Coleoptera: Curculionidae). Journal of Stored Products Research, v.55, p.6-14, 2013. DOI: 10.1016/j. jspr.2013.06.001.
RIBEIRO, L. do P.; VENDRAMIM, J.D.; GONÇALVES, G.L.P.; ANSANTE, T.F.; GLORIA, E.M.; LOPES, J. de C.; MELLOSILVA, R.; FERNANDES, J.B. Searching for promising sources of grain protectors in extracts from Neotropical Annonaceae. Boletín Latinoamericano y del Caribe de Plantas Medicinales y Aromáticas, v.15, p.215-232, 2016.

RIBEIRO, L. do P.; ZANARDI, O.Z.; VENDRAMIM, J.D.; YAMAMOTO, P.T. Comparative toxicity of an acetogeninbased extract and commercial pesticides against citrus red mite. Experimental and Applied Acarology, v.64, p.87-98, 2014. DOI: 10.1007/s10493-014-9810-2.

RODRIGUES, A.M.S.; DE PAULA, J.E.; DEGALLIER, N.; MOLEZ, J.F.; ESPÍNDOLA, L.S. Larvicidal activity of some Cerrado plant extracts against Aedes aegypti. Journal of the American Mosquito Control Association, v.22, p.314-317, 2006. DOI: 10.2987/8756-971X(2006)22[314:LAOSCP]2.0.CO;2.

ROH, H.S.; LIM, E.G.; KIM, J.; PARK, C.G. Acaricidal and oviposition deterring effects of santalol identified in sandalwood oil against two-spotted spider mite, Tetranychus urticae Koch (Acari: Tetranychidae). Journal of Pest Science, v.84, p.495-501, 2011. DOI: 10.1007/s10340-011-0377-y.

SHAALAN, E.A.-S.; CANYON, D.; YOUNES, M.W.F.; ABDEL-WAHAB, H.; MANSOUR, A.-H. A review of botanical phytochemicals with mosquitocidal potential. Environment International, v.31, p.1149-1166, 2005. DOI: 10.1016/j. envint.2005.03.003

SILVA, F.R. da; VASCONCELOS, G.J.N. de; GONDIM JÚNIOR, M.G.C.; OLIVEIRA, J.V. de. Toxicidade de acaricidas para ovos e fêmeas adultas de Euseius alatus Deleon (Acari: Phytoseiidae). Revista Caatinga, v.19, p.294-303, 2006.

VAN LEEUWEN, T.; VAN POTTELBERGE, S.; NAUEN, R.; TIRRY, L. Organophosphate insecticides and acaricides antagonise bifenazate toxicity through esterase inhibition in Tetranychus urticae. Pest Management Science, v.63, p.11721177, 2007. DOI: 10.1002/ps.1453.

VAN LEEUWEN, T.; VONTAS, J.; TSAGKARAKOU, A.; DERMAUW, W.; TIRRY, L. Acaricide resistance mechanisms in the two-spotted spider mite Tetranychus urticae and other important Acari: a review. Insect Biochemistry and Molecular Biology, v.40, p.563-572, 2010. DOI: 10.1016/j.ibmb.2010.05.008.

WHALON, M.E.; MOTA-SANCHEZ, D.; HOLLINGWORTH, R.M. Analysis of global pesticide resistance in arthropods. In: WHALON, M.E.; MOTA-SANCHEZ, D.; HOLLINGWORTH, R.M. (Ed.). Global pesticide resistance in arthropods. Cambridge: CAB International, 2008. p.5-31. DOI: 10.1079/9781845933531.0005.

Received on October 25, 2016 and accepted on January 17, 2017

Pesq. agropec. bras., Brasília, v.52, n.9, p.707-714, set. 2017

DOI: 10.1590/S0100-204X2017000900002 